\title{
Delving the Relationship between Teacher Empowerment and Job Satisfaction among Iranian EFL Teachers in Tehran Aviation University
}

\author{
Fatemeh Azimi Amoli \\ Department of English, Ilam University, Ilam, Iran \\ Maryam Youran \\ Department of English, Payam-e Noor University, Tehran, Iran
}

\begin{abstract}
The purpose of this study was to examine the relationship between teachers' empowerment and job satisfaction. The surveys used in this study contain School Participant Empowerment Scale (SPES) measured teacher perceived empowerment, the Teacher Job Satisfaction Questionnaire (TJSQ) measured teacher job satisfaction, and the demographic survey included age, educational background and gender. SPES measured six different dimensions o f empowerment: Decision-making, professional growth, status, self-efficacy, autonomy, and impact, along with an overall total and TJSQ includes nine factors of satisfaction: Supervision, colleagues, working conditions, pay, and responsibility. The result indicated that significant correlations were found between total teacher empowerment and total teacher job satisfaction. However, there was no correlation between factor of security in job satisfaction scale and the three teacher empowerment scales of professional growth, status, and autonomy. There was also no correlation found between the teacher job satisfaction factor of recognition and the three teacher empowerment dimensions of decision-making, selfefficacy and impact. In the other hand, there are significant differences in the demographic variables of educational background and gender with regards to teacher empowerment and job satisfaction.
\end{abstract}

Index Terms - teacher empowerment, job satisfaction

\section{INTRODUCTION}

\section{A. Teacher Empowerment}

Due to previous researches, teacher empowerment is a field that teachers should have enough jurisdictions in the professional development process to have self-efficacy. Short (1992) stated that teacher empowerment is as a professional development process including professional knowledge base, higher teaching efficacy, and promote decision-making to meet the requirement of education. The three key issues accentuated in the study included: (a) empowerment is a learning process which grows the ability of teachers to achieve authority and let them to create a more effective learning environment, (b) teachers should obtain a higher self awareness to enhance the learning environment, and (c) empowering motivation is a factor which improve teacher's sense of power and consequently increase self-efficacy.

Whitaker and Moses (1990) expressed that five factors which enhance empowerment can be included to: (a) make a sense of self-confidence in teachers, (b) liberate teachers, foster their collaboration, and decreases alienation, (c) change bureaucracy, (d) arouse growth and renewal, and (e) improve cooperation.

Blase and Blase (1994) investigated some points about the concept of teacher empowerment concentrating on professional structure, improving the teaching profession, and increase independence. On the other hand, Mahrenhoztion (1996) focused on changing old concepts, motivating teachers to become involved, making new ideas and innovations in order to grow their professional knowledge base.

Blanchard and Carlos (1996) accentuated some key pinpoints. First, employees must be responsible and managers need to trust employees. Second, rewards create more motivation and enhance self-efficacy of the organization and encourage an innovation. Third, training and development is vital in the process. Fourth, the more trust, the more motivation can be predicted.

According to Short's (1992) study teacher empowerment as a professional development process containing professional knowledge base, higher teaching efficacy, self-efficacy, and increasing participation in decision-making to meet the goals of education. The three key points in the study include: (a) empowerment is a learning process increasing the ability o $f$ teachers to achieve authority and allowing them to make a more efficient learning environment, (b) 
teachers should have a higher self awareness and improve the learning environment, and (c) empowering teachers can enhance their motivation and improve their sense of responsibility in order to increase overall efficacy.

Riley (1995) indicated that teachers are the most important resource in the school restructuring processes. When teachers have empowerment, their authority structure changes and If this can change, then empowerment can be more easily performed as well as school restructuring can be accomplished. Empowered teachers can make greater contributions, and seeing the changes that these contributions make, can further add to and sustain the momentum.

\section{B. Job Satisfaction}

According to Zembylas \& Papanastasiou (2004), Job satisfaction is an effective feedback to the situation which a person involved at work. Thus it is a distinguished relationship between what one wants from teaching and what one discerns it is suggesting to a teacher.

Thompson (1997) stated that some aspects, associated with teacher satisfaction, include salary, support from supervisor, and accessibility of resources. These and other factors of teachers' working environment have been recognized as factors that increased teacher dissatisfaction and to teacher's attrition. Therefore, Travers \& Coopers (1996) indicated that when teachers are not satisfied with their working conditions, they are intended to leave the profession (Travers \& Cooper, 1996).

In a study of the job satisfaction of high school journalism teachers, Dvorak and Phillips (2001) used Herzberg's twofactor theory to identify predictors of job satisfaction. The results of the study indicated that the teachers felt generally satisfied. If given the opportunity to return to college to start over again, $70 \%$ of the teachers indicated they would again choose teaching. Dvorak and Phillips found a mix of intrinsic and extrinsic factors predicted the job satisfaction of these teachers. Intrinsic predictors included advancement, work itself, and responsibility. In contrast to Herzberg's theory, working conditions, salary, and job security were extrinsic factors which were significant predictors of job satisfaction for this sample.

\section{Relationships between Teacher Empowerment and Job Satisfaction}

The beginning studies about teacher empowerment and job satisfaction started in the 1990's in elementary and high schools and the finding displayed that there was a positive relationship between teacher empowerment and job satisfaction.

Short \& Rinehart (1992) examined teachers in a Reading Recovery program and found a positive correlation between teacher empowerment and job satisfaction. The reason was standardized management policies, therefore, teacher empowerment, job satisfaction and responsibility enhanced.

Wu (1995) examined the relationship among teacher empowerment, job satisfaction and organizational commitment in Pennsylvania and the findings displayed that when teachers distinguish empowerment, both job satisfaction and consequently organizational commitment enhances.

Hatchett (1995) investigated teacher empowerment, transformational leadership and job satisfaction in Florida and result that empowerment, transformational leadership, and job satisfaction had a positive correlation.

Fritsch (1995) proclaimed assertively that faculty senates and policy practices in Virginia schools had a positive perception of empowerment in teachers caused to increase job satisfaction. Likewise, Lanney (1998) studied high school teachers' empowerment and job satisfaction, finding a positive correlation between teacher perception of empowerment and job satisfaction.

Klecker (1996a) studied 180 venture schools in Ohio also finding a positive correlation between empowerment and job satisfaction.

Empowerment and job satisfaction represent that these two factors could have a positive relationship. While there has been limited unification of the teacher empowerment into other areas like job satisfaction in Iran so this research used studies of job satisfaction and teacher empowerment which indicates a need for further study.

\section{Statement of Problem}

In Iran, the traditional educational system has many restrictions on the teachers. Teachers cannot change any of textbook. As a result, teachers do not have any control of the syllabus, and are cannot participate in decision-making at school. So teachers don't feel they are empowerment and are not satisfied in their jobs. Therefore, how to empower teachers and improve their job satisfaction is an important issue in Iran. In Iran, the educational system is the assessment of students and their performance which orders what academic opportunities are available to them in school. Consequently, evaluation of teachers is assessed by variables like how their students perform, and not by other variables in the classroom. Because of this reason, teachers have not been empowered to participate in policy-making activities outside of their classrooms. Short (1992) expressed that teacher empowerment contains teachers participating in policy and decision-making, acquiring new professional skills, having approch to professional development, and performing changes. As an instructor and decision maker in the classroom, a teacher needs to enhance skills to learn and solve problems sequentially, develop educational programs and perform changes.

\section{E. Significance of the Study}


If empowering teachers increases their job satisfaction, therefore this increased job satisfaction enhances the quality of teaching and the general efficiency of schools. The traditional educational system in Iran has many restrictions for the teachers. Teachers cannot choose what kind of textbook to use even though this action is neither more helpful for students, nor can they participate in school decision-making and planning. Traditional educational concepts contain focusing on teaching and not being involved in any decision-making activities have been an obstacle to change. In order to enhance the system, it is vital to determine how job empowerment can promote change and increase job satisfaction for teachers. The results of this study can encourage comprehending to recognize relationships, strengths and weaknesses, and appropriate interference, improve the quality of teaching and increase school efficiency.

\section{Methodology}

\section{A. Research Design}

The correlational research method used in this study is related to evaluating the relationships between two or more variables. The study was used to assess randomly selected teachers of Aviation University, employing quantitative data collection techniques.

\section{B. Research Hypotheses}

H1: There is no relationship between total teacher and total teacher job satisfaction.

$\mathrm{H} 2$ : There is no significant difference in total teacher empowerment based on different demographic characteristics o $\mathrm{f}$ teachers (age, educational background and gender).

H3: There is no significant difference in total teacher job satisfaction based on different demographic characteristics of the teacher (age, educational background and gender).

\section{Instrumentation}

\section{Demographic survey}

This survey included gender, age, school size, and educational background.

\section{School participant empowerment scale}

Short and Rinehart (1992) designed the SPES instrument in 1992. It consists of 38 items addressing six dimensions:

Decision-making, professional growth, status, self- efficacy, autonomy, and impact. Developed to measure school participant (teacher) empowerment, the design measures several items such as trust, communication, and structures for involvement, risk taking, and critical incidents. In addition, topics such as opportunities for decision-making, control over daily schedule, opportunities for growth and development can also be empowering aspects of a teacher's job.

\section{Teacher job satisfaction questionnaire}

Lester (1987) designed the TJSQ to investigate teachers' job satisfaction. This instrument has 66 items divided into nine factors including supervision, colleagues, working conditions, pay, responsibility, work itself, advancement, security, and recognition.

\section{Data Analysis}

For the investigating the hypotheses, a t-test was used to test the mean difference between two variables, teacher empowerment and job satisfaction and total teacher empowerment and total teacher job satisfaction on teachers' educational based on background, gender, and age.

\section{RESULTS AND DisCUSSIONS}

\section{A. Testing Null Hypothesis One}

The primary null hypothesis was tested by using the Pearson product-moment correlation coefficients. According to Gau (2001), If the correlation coefficient between two variables was below 0.500, there is a correlation between two variables. The results are shown in Table 1.

TABLE 1.

PEARSON PRODUCT-MOMENT CORRELATION COEFFICIENT OF TEACHER EMPOWERMENT AND JOB SATISFACTION

\begin{tabular}{|l|l|l|l|l|l|l|l|}
\hline $\begin{array}{l}\text { TE Dimension/ } \\
\text { TJ Factors }\end{array}$ & $\begin{array}{l}\text { Decision- } \\
\text { making }\end{array}$ & $\begin{array}{l}\text { Professional } \\
\text { growth }\end{array}$ & Status & Self- efficacy & Autonomy & Impact & TE \\
\hline Supervision & .484 & .307 & .213 & .280 & .195 & .405 & .418 \\
\hline Colleagues & .346 & .157 & .150 & .205 & .189 & .267 & .291 \\
\hline Working & .280 & .157 & .195 & .236 & .235 & .280 & .293 \\
\hline Condition Pay & .387 & .381 & .338 & .386 & .293 & .267 & .447 \\
\hline Responsibility & .341 & .431 & .526 & .578 & .453 & .422 & .544 \\
\hline Work itself & .396 & .347 & .317 & .422 & .323 & .409 & .460 \\
\hline Advancement & .386 & .274 & .185 & .305 & .123 & .338 & .352 \\
\hline Security & .190 & .080 & .016 & .117 & .054 & .158 & .142 \\
\hline Recognition & .092 & -.117 & -.212 & -.040 & -.098 & .021 & .499 \\
\hline TJ Total & .502 & .355 & .314 & .429 & .320 & .465 & .508 \\
\hline
\end{tabular}

Note: $\mathrm{TE}=$ Teacher empowerment and $\mathrm{TJ}=$ Teacher job satisfaction 
The results between the total teacher empowerment and total teacher job satisfaction displayed the correlation coefficient at $r=.508$, that is, there is a positive correlation between teacher empowerment and teacher job satisfaction. But the table 1 also represents that the teacher job satisfaction factor of security and the teacher empowerment dimensions of professional growth $(r=.080)$, status $(r=.16)$, and autonomy $(r=.054)$ have no correlation with each other. Even, there are no correlation between teacher job satisfaction of recognition, the teacher empowerment dimensions of decision-making $(r=.092)$, self-efficacy $(r=-0.40)$ and impact $(r=.021)$. Therefore, the primary hypothesis was rejected.

\section{B. Testing of Null Hypothesis Two}

Hypothesis two displays that there is no significant difference in total teacher empowerment based on different teachers' demographic characteristics (age, educational background and gender). Table 2 indicates that the $\mathrm{p}$ value for total teacher empowerment is being .00 (-.769). It is below the significance level of .05, so total teacher empowerment is significantly different based on the demographic variable of educational background. Based on the higher mean, teachers who have Master degrees perceive higher empowerment than teachers who only have Bachelor degrees.

TABLE 2.

T-TEST (TOTAL TEACHER EMPOWERMENT BASED ON TEACHER'S EDUCATIONAL BACKGROUND)

\begin{tabular}{|l|l|l|l|l|l|l|}
\hline Teacher Empowerment & Background & N & M & SD & Sig & T \\
\hline \multirow{2}{*}{ Total } & Bachelor & 317 & 3.4156 & .47 & .00 & -.769 \\
\cline { 2 - 5 } & Master & 93 & 3.4624 & .67 & & \\
\end{tabular}

As shown in Table 3, the $\mathrm{p}$ value for total teacher empowerment being $.01(t=.408)$. Since it is below the significance level of .05, the total teacher empowerment is significantly different based on gender.

TABLE 3.

T-TEST (TOTAL TEACHER EMPOWERMENT BASED ON TEACHER'S GENDER)

\begin{tabular}{|l|l|l|l|l|l|l|}
\hline Teacher Empowerment & Gender & $\mathrm{N}$ & $\mathrm{M}$ & $\mathrm{SD}$ & $\mathrm{Sig}$ & $\mathrm{T}$ \\
\hline \multirow{2}{*}{ Total } & Male & 180 & 3.47 & .56 & \multirow{2}{*}{.01} & .408 \\
\cline { 2 - 5 } & Female & 230 & 3.38 & .47 & & \\
\hline
\end{tabular}

As Table 4 indicates, the total teacher empowerment is .287 and greater than the significance level o $f .05(F=1.261)$ resulting in no significant difference between total teacher empowerment based on teacher's age.

TABLE 4.

ANOVA (TOTAL TEACHER EMPOWERMENT BASED ON TEACHER'S AGE)

\begin{tabular}{|l|l|l|l|l|l|l|}
\hline Teacher Empowerment & Age & SS & df & MS & F & Sig \\
\hline \multirow{4}{*}{ Total } & Between group & 1.005 & 3 & .335 & 1.261 & .287 \\
\cline { 2 - 5 } & Within group & 107.791 & 406 & .265 & & \\
\cline { 2 - 5 } & Total & 108.795 & 409 & & & \\
\hline
\end{tabular}

According to Table 5, there is no significant difference in total teacher job satisfaction based on different demographic characteristics of teachers.

\section{Testing the Null Hypothesis Three}

Table 5 indicates all nine factors of teacher job satisfaction having p values greater than the significance level of .05, therefore, there is no significant difference of teacher job satisfaction based on the demographic variable of teacher's educational background.

TABLE 5.

T-TEST (TOTAL TEACHER JOB SATISFACTION BASED ON TEACHERS EDUCATIONAL BACKGROUND)

\begin{tabular}{|l|l|l|l|l|l|l|}
\hline Factor & Background & $\mathrm{N}$ & $\mathrm{M}$ & $\mathrm{SD}$ & Sig. & $\mathrm{T}$ \\
\hline \multirow{2}{*}{$\begin{array}{l}\text { Job } \\
\text { Satisfaction }\end{array}$} & Bachelor & 317 & 2.89 & .36 & .325 & 1.247 \\
\cline { 2 - 5 } & Master & 93 & 2.94 & .30 & & \\
\hline
\end{tabular}

Table 6 displays all of the nine teacher job satisfaction factors having $\mathrm{p}$ values greater than the significance level of .05 which represent there is no significant difference based on the demographic variable of gender.

TABLE 6.

T-TEST (TOTAL TEACHER JOB SATISFACTION BASED ON GENDER)

\begin{tabular}{|l|l|l|l|l|l|l|}
\hline Factors & Gender & $\mathrm{N}$ & $\mathrm{M}$ & $\mathrm{SD}$ & Sig. & $\mathrm{T}$ \\
\hline \multirow{2}{*}{ Job Satisfaction } & Male & 180 & 2.97 & .37 & \multirow{2}{*}{.385} & \multirow{3}{*}{3.553} \\
\cline { 2 - 5 } & Female & 230 & 2.85 & .33 & & \\
\hline
\end{tabular}

Based on the significance level $(\mathrm{p}<.05)$, only two factors (Advancement and Recognition) are significant for job satisfaction based on age as shown in Table 7. 
TABLE 7.

ANOVA (TOTAL TEACHER's JOB SATISFACTION BASED ON AGE)

\begin{tabular}{|l|l|l|l|l|l|l|}
\hline Factor & Age & SS & DF & MS & F & Sig. \\
\hline \multirow{3}{*}{$\begin{array}{l}\text { Job } \\
\text { Satisfaction }\end{array}$} & Between group & .490 & 3 & .163 & 1.299 & .247 \\
\cline { 2 - 5 } & Within group & 51.091 & 406 & .126 & & \\
\cline { 2 - 5 } & Total & 51.581 & 406 & & & \\
\hline
\end{tabular}

\section{CONCLUSION}

Teacher empowerment. Due to the comparison to other researchers, Pan (2001) investigated teacher empowerment and job satisfaction of instructors in public elementary schools in Taiwan and result that the average score of all factors of teacher empowerment was 3.57. Pan took into account the ratings of self-efficiency, professional growth, status, autonomy, impact and decision-making. In job satisfaction section, the average overall score of all scales was 3.55 using dimensional ratings of coworker relations, mental reward, the work itself, salary, promotion, and administrative leadership.

Liang (2004) pointed out the relationship between teacher empowerment, commitment, and effectiveness among junior high school teachers in the capital city of Taipei. The results showed that these teachers have a high degree of teacher empowerment and can participate in decision-making actively and being more independent.

Klecker and Loadman (1996a) investigated 10,544 teachers in 307 Venture Capital schools, again in the United States and this time in the state of Ohio, finding the total mean of teacher empowerment scoring as 3.82. The highest individual dimension was professional growth at 4.19, followed by self-efficacy, status, impact, and decision-making, and autonomy the lowest at 3.08 .

Teacher job satisfaction. Total teacher job satisfaction was at an intermediate level of 3.01 with responsibility (3.42) as the leading factor, followed by work itself (3.16), colleagues (3.00) working condition (2.97), advancement (2.96), supervision (2.90), security (2.75), pay (2.65) and recognition (2.53) being the last. Only three factors (responsibility, work itself, colleagues) were in an intermediate level with the remaining factors were in a low level. Hsu (2002) displayed resource room program teachers at junior high schools which are accompanied with his work. Chen (2004) examined job satisfaction for junior high school teachers focusing on learning as an integrated activity in Taipei, and represented that teachers were satisfied with their work as well. Overall, the previous studies and this study displayed that teachers in Aviation University were satisfied at their job.

Correlation between teacher empowerment and job satisfaction. This study has showed a significant correlation between total teacher empowerment in all six dimensions, and between total teacher job satisfaction in all but two of the nine different factors are not correlated. Pan (2001) in Taiwan found significant correlation, the same as those found by Klecker and Loadman (1998c), Lanney (1998), Short and Rinehart (1992), and Wu (1995) pointed out the significant correlation between empowerment and job satisfaction along with organizational commitment in Pennsylvania teachers, in addition, Hatchett (1995) in south Florida added transformational leadership to these variables. This significant relationship between empowerment and job satisfaction of teachers is not limited to this study or to a specific region of the world.

Davis (1994) resulted that teacher's job satisfaction based on total teacher empowerment was not statistically significant.

Planner-Hardy (1983) found there were no statistically significant relationships between the degree of involvement in district-wide decisions and job satisfaction for elementary teachers.

Furthermore, Ludolph (1985) did not find any significant relationships between satisfaction and the degree of decision-making for teachers. Conversely, a number of studies found a positive relationship between teacher empowerment and teacher job satisfaction (Miskel, Fevurly \& Stewart, 1979; Enderle, 1997; Rinehart and Short, 1993; Davis, 1994; Klecker, 1996).

\section{IMPLICATION FOR FURTHER RESEARCH}

Additional research is required to determine the relationship between teacher empowerment and the job satisfaction of the teachers. The future researches contain:

- Replication of this study with samples including schools and English institutes

- Further research to investigate factors, other than teacher empowerment dimensions that may be influential teachers' job satisfaction.

- Additional research to determine the relationship between years experience and job satisfaction.

\section{Theoretical Implications}

The findings from this research with English teachers were consistent with the findings from other studies with regular academic teachers which have also found positive correlations between these constructs (Klecker \& Loadman, 1996b; Kim, 2002; Wu \& Short, 1996). Therefore, we can conclude that the relationship between empowerment on job satisfaction is likely the same for all content area teachers. Conversely, the more empowerment decreases, the more job satisfaction also decreases. For this study, empowerment served as an internal index which the work environment 
satisfied the teacher's requirements and thus were indicators of satisfaction which is presented by the Theory of Work Adjustment (Dawis et al., 1968) and Herzberg's Two-Factor Theory (Herzberg et al., 1959). These theories assumed that individuals are motivated more by intrinsic factors of their work. The findings of this study display that empowerment may be an important factor that aids to overall job satisfaction. In addition, this study indicates better understanding of how these two issues are related.

According to Johnson (2004) \& Warr (1991), the educational literature has represented a consistent relationship between teacher retention and job satisfaction. Dawis et al. (1968) expressed that the greater the balance between the individual and his/her work environment, the greater the chance of tenure. Therefore, teacher retention ultimately may be increased. The finding of a significant relationship between the constructs of job satisfaction and empowerment in this study provided support for the suggestion that administrators and school personnel create a work environment which emphasizes teacher empowerment.

Furthermore, Shen (1997) indicated work environment can be influential for teachers to control the school and teaching policies leads to greater levels of job satisfaction and empowerment and ultimately, increased teacher retention.

Quaglia, et al. (1991) also displayed that school administrators are sensitive to the importance of empowerment to teacher satisfaction levels and provide opportunities for teacher participation within the school. Training should be given to administrators on the types of leadership so that this professional process will continue to express high levels of empowerment and job satisfaction and ultimately have increased teacher retention. School administrators should concentrate on creating an empowering work environment for teachers by increasing participation in decision making, providing opportunities for professional growth, fostering professional respect between colleagues, promoting selfefficacy, allowing for teacher autonomy, and welcoming teacher input on school-related issues.

\section{RECOMMENDATION}

According to these results in Aviation University in Iran, the following recommendations are made for instructors and future researchers.

For instructors. The recommendation for instructors is to differentiate between your responsibilities and what empowerment you have. One responsibility for instructors is to participate in the school's decision-making process. In so doing, they will empower themselves and their profession, teach more effective, and reform their education more successful. The combination of developing and enhancing both professional teacher knowledge and their competency, will either promote teacher skills or the school's performance, and can improve student learning, which leads to a better performance.

For future researchers. The recommendation for future researchers is to perform research in different levels o $\mathrm{f}$ instruction (other than university) and in different areas.

\section{REFERENCES}

[1] Blanchard, K. \& Carlos, J. P. (1996). Empowerment takes more than a minute. San Francisco: Berrett Koehler.

[2] Blase, J. J. \& Blase, J.R. (1994). Empowerment teachers: what successful principal do. (Report No. ISBN 080396092 I). Thousand Oaks, CA: Corwin Press. ERIC Document Reproduction Service No. ED 377576.

[3] Chen Y. W. (2004). A Study on Job Satisfaction of Taipei Junior High School Teachers in Integrative Activity Learning Area. Journal of Taichung Teachers College, 18(1).

[4] Davis, J. (1994). Teacher and principal empowerment in elementary schools in Eastern Washington (Doctoral dissertation, Gonzaga University, 1994). Dissertation Abstracts International, 55(4), 0811 A.

[5] Dvorak, J., \& Phillips, K. D. (2001). Job satisfaction of high school journalism educators. Paper presented at the annual meeting of the Association for Education in Journalism and Mass Communication, Scholastic Journalism Division, Washington, D.C. (ERIC Document Reproduction Service No. ED456466).

[6] Enderle, M. (1997). Decision-making involvement and job satisfaction of Accelerated School's elementary teachers (Doctoral dissertation, University of Missouri-Columbia, 1997). Dissertation Abstracts International, 59(1), 2264A.

[7] Gau, I. F. (2001). Psychology and Educational Statistics. Chicago, IL: American Psychological Association

[8] Hatchett, M. E. (1995). An analysis of teacher empowerment, transformation leadership and job satisfaction in the elementary school. Dissertation Abstracts International, 5(5(11), 4223.

[9] Klecker, B. M. \& Loadman, W. E. (1996a). Dimensions o f teacher empowerment: Identifying new roles fo $r$ classroom teachers in restructuring schools. (Report No. MSERA-SCP-96-11). Tuscaloosa, AL: Mid-South Educational Research Association. ERIC Document Reproduction Service No. ED405304.

[10] Klecker, B. M. (1996a). A study o f teacher empowerment in Ohio's venture capital school. Dissertation Abstracts International, 57(3), 533.

[11] Kleeker, B. (1996). A study of teacher empowerment in Ohio's Ventura Capital Schools (Doctoral dissertation, Ohio State University, 1996). Dissertation Abstracts International, 57(02), 0533A.

[12] Lanney, N. E. (1998). The perceptions o f teacher empowerment and job satisfaction among Jackson County high school teachers. Dissertation Abstracts International, 60(4), 959.

[13] Lester, P. E. (1987). Development and factor analysis of teacher job satisfaction Questionnaire. Educational and Psychological Measurement, 47, 223-233.

[14] Liang,w. Y. (2004). A study on the relationship of the teacher empowerment, teaching Commitment and teaching effectiveness of the junior high school teachers in Taipei. NNEST Newsletter, 5(2), 3-5. 
[15] Ludolph, J. (1985). An examination of participation in decision making and the perceptions of satisfaction for elementary school principals and teachers in the state of Illinois. (Doctoral dissertation. Northern Illinois University, 1985). Dissertation Abstracts International, 46(09), 2505.

[16] Mahrenhoztion, D. B. (1996). A descriptive study of the strategies used by principals to empower elementary teachers and the extent to which the teacher perceives themselves as empowered by the use of those strategies. Unpublished dissertation. Laveme, CA: University o f LaVeme.

[17] Miskel, C., Fevurly, R., \& Stewart, J. (1979). Organizational structures and processes, perceived school effectiveness, loyalty and job satisfaction. Educational Administration Quarterly, 75(3), 97-118.

[18] Pan, A. (2001). The study of the relationship on teacher empowerment and jo b satisfaction in elementary school. Unpublished master's thesis, National Taiwan University, Taipei, Taiwan.

[19] Planner-Hardy, M. (1983). Decision involvement and job satisfaction in elementary principals. (Doctoral thesis, University of Wisconsin-Madison, 1983). Dissertation Abstracts International, 44(05), 1280A.

[20] Riley, R. W. (1995). Remarks on the 1995 goals in the 2000 teacher forum [Abstract]. Retrieved January 192004 from: http://www.ed.gov/speeches/11.12.95.html.

[21] Rinehart, J., \& Short, P. (1993). Job satisfaction and empowerment among teacher leaders, reading recovery teachers, and regular classroom teachers. Education, 114(4), 570-581.

[22] Short, P. M. (1992). Dimensions of teacher empowerment. (Report No. AERA-RR-924). Chicago, IL: American Educational Research Association.

[23] Short, P. M., \& Rinehart, J. S. (1992). School participant empowerment scale: Assessment of level of empowerment within school environment. Educational and Psychological Measurement, 52(4), 951-960.

[24] Thomas, K. W., \& Velthouse, B. A. (1990). Cognitive elements of empowerment: An interpretive model o f intrinsic task motivation. Academy of Management Review, 75(4), 666-681. U.S. Department o f Education. (1995). School-based reformlessons from a national study. Retrieved January 28, 2004 from: http://www.ed.gov/pubs/Reform/pt2a.html.

[25] Travers, C. J., \& Cooper, C. L. (1996). Teachers under stress. Stress in the teaching profession. London7 Routledge.

[26] Whitaker K. S. \& Moses, M. C. (1990). Teacher empowerment: A key to restructuring. Clearing House, 64(2), 127-130.

[27] Wu, Y. Y. (1995). Relationships among teachers' perceptions of empowerment, job satisfaction, and organizational commitment in public schools. Dissertation Abstract International 55(9), 2679.

[28] Zembylas, M. and Papanastasiou, E. (2004). "Job satisfaction among school teachers in Cyprus", in Journal of Educational Administration, 42, 3: 357-374.

Fatemeh Azimi Amoli is a Ph.D Candidate in Ilam University in TEFL. She is teaching English courses in some Universities and published many articles and two books. Her area of interests includes in Leadership Style, Teacher Professional Development, and Psycholinguistics.

Maryam Youran graduated in TEFL in Takestan University. She is teaching English courses in Payam-e-noor University, Ilam Branch. She likes to study in syntax and discourse field. 